\title{
Testing Fairtrade's Labour Rights Commitments in South Asian Tea \\ Plantations
}

\section{A Good Match between Civic and Industrial Conventions?1}

\section{Karin Astrid Siegmann}

International Institute for Social Studies of Erasmus University Rotterdam (ISS), The Hague/the Netherlands

with Sajitha Ananthakrishnan, Centre for Development Studies (CDS), Thiruvananthapuram/India, Karin Fernando, Centre for Poverty Analysis (CEPA), Colombo/Sri Lanka, K J Joseph, CDS, Romeshun Kulasabanathan, CEPA, Rachel Kurian, ISS, P K Viswanathan, Department of Management, Amrita University, Kochi/India

Keywords

convention theory, Fairtrade International, India, living wage, plantation workers, Sri Lanka, tea plantations, trade unions

Abstract

This article looks at the effectiveness of Fairtrade's labour rights commitments through the lens of convention theory. It zooms in on workers involved in the cultivation, harvest, and processing of tea as Fairtrade's single most important plantation product. Based on data generated in 2016 through a mixed methods study on the role of Fairtrade certification for tea plantation workers in India and Sri Lanka, we find a wide gulf between living wages and plantation workers' actual earnings, as well as a separation between Fairtrade's role and trade unions. This "test" of certification standards as a compromise between 'civic' conventions concerned with equality and productivity-oriented "industry" conventions suggests that, in actual certification practice, industrial conventions reign.

\footnotetext{
${ }^{1}$ We thank participants of the Fair Trade International Symposium "Fair Trade and the SDGs: Investigating the Fairness of Sustainable Development," 26-28 June 2018 at the University of Portsmouth, as well as two anonymous reviewers for their excellent suggestions to improve this article. All remaining errors are solely ours.
} 


\section{Introduction}

Fairtrade is committed to fighting poverty and contributing towards decent work in global value chains. Set up as a social and environmental certification system, Fairtrade was originally designed to improve the position of peasant farmers. In 1994, its certification was extended to tea plantations with the argument “[...] that if the goal was to benefit 'disadvantaged producers', then landless laborers, who are often poorer than farmers, should be included" (Raynolds, 2014: 502).

Fairtrade's New Workers Rights Strategy, ${ }^{2}$ which was reformulated in 2012, emphasises the guarantee of a living wage and support for worker organisation as strategic priorities (Fairtrade International, 2012). This two-pronged approach to labour rights complements the organisation's support for the social development of workers' communities through the payment of the Fairtrade Premium, governed by the Fairtrade Premium Committee (FPC), a body consisting of elected worker representatives and management advisors. The Fairtrade certification Standard for Hired Labour ${ }^{3}$ was scarfed in 2014 to reflect these strategic priorities (Fairtrade International, 2014).

Assessments of the effectiveness of Fairtrade's labour programme are few and inconclusive. The early optimism that the extension of Fairtrade certification to plantations could contribute to improving the plight of landless agricultural workers (Reed, 2009: 15) has given way to criticism that Fairtrade organisations have failed to be transformative because of their neglect of the intersecting class-, gender-, and ethnicity-based identities and struggles of plantation labourers (Besky, 2015; Staricco, 2019).

In this article, we zoom in on workers involved in the cultivation, harvest, and processing of Fairtrade's single most important plantation product: tea. Tea was the first plantation commodity certified by a Fairtrade member organisation. With 93,160 plantation workers employed to harvest and process it in 2016, tea involves a higher number of wageworkers than any other Fairtrade product. Over two thirds of those workers live and work in India and Sri Lanka (Fairtrade International, 2018: 87).

South Asian ${ }^{4}$ tea plantation workers' poverty and disempowerment are steeped in hierarchies of coloniality, class, ethnicity, and gender. Now embedded in a global value chain dominated by a few multinational tea brands, labour governance in South Asian tea estates still closely resembles the time when the British colonial government stimulated the development of large-scale tea production in India and Sri Lanka in the early 19th century (Bhowmik, 2011; Kurian, 1989).

We look at the effectiveness of Fairtrade's labour rights commitments for these wageworkers through the lens of convention theory. Convention theory posits that coordination of actions is guided and justified by shared cognitive frames or "conventions" (Cheyns and Riisgaard, 2014: 413). It distinguishes common principles governing the inspired, domestic, fame, civic, market, and industry realms, and examines their

\footnotetext{
2 In the following, "Strategy".

${ }^{3}$ In the following, "Standard".

${ }^{4}$ In the context of this article, the term "South Asia" refers to India and Sri Lanka.
} 
negotiation. The Fairtrade Standard has often been characterised as a compromise between civic conventions concerned with equality and productivity-oriented industry conventions.

More specifically, we ask whether the negotiation of such different norms matters for the effectiveness of Fairtrade commitments to a living wage and to support for worker organisation in South Asian tea plantations. Our analysis is based on data generated in 2016 through a mixed methods study on the role of Fairtrade certification for tea plantation workers in India and Sri Lanka commissioned by Fairtrade International. We find a wide gulf between living wages and South Asian tea plantation workers' actual earnings, as well as a separation between Fairtrade's role and trade unions. This suggests that industrial rather than civic conventions reign in actual certification practices.

We develop our argument in six steps. The next section sketches the context of the South Asian tea value chain, while Section 2 examines Fairtrade certification through the lens of convention theory. The methodology of this article is presented in Section 3. It is applied in Section 4, which analyses the role of certification for South Asian tea plantation workers' wages and collective rights. Section 5 discusses these findings from the perspective of convention theory. Section 6 concludes with an outlook for the future of Fairtrade certification.

\section{South Asian Tea Plantation Workers' Bitter Harvest ${ }^{5}$}

The present-day tea value chain features an "hourglass shape," with a large number of upstream farmers and workers, a few processors and traders in the middle, and many retailers and consumers (Mohan, 2016: 55). About $85 \%$ of the tea processing, retailing, trade, blending, and packaging are in the hands of relatively few multinationals (Glocal Research/ICN, 2016: 7), enabling them to skim a significant proportion of value in the chain (Lalitha et al., 2013: 24).

India and Sri Lanka hold key positions in this tea value chain, with India being the second global tea producer, and Sri Lanka the second exporter after China (FAOSTAT, 2019). In India, most of the tea produced originates from North Indian states, mainly from the Assam valley (52\% of the total Indian production). The bulk of tea produced in South India is cultivated in Tamil Nadu (12\%), followed by Kerala (4\%) (Indian Tea Association, 2019). The approximately 1,500 large tea plantations in India employ over a million workers, overwhelmingly in North India (Bhowmik, 2015: 30; Tea Board of India, 2016: 83).

Sri Lankan tea mainly originates from the highlands of the Nuwara Eliya, Badulla, and Kandy districts. In Sri Lanka, there were 427 large estates - including both tea and rubber - operating in 2012, owned by 20 private and seven state companies. Wageworkers in these large estates amounted to 193,412 individuals (Ministry of Plantation Industries, 2013: 145, 148).

\footnotetext{
${ }^{5}$ This section draws on Siegmann et al. (forthcoming).
} 
While India and Sri Lanka are important players in the global tea value chain, being employed in South Asian tea cultivation and processing does not end workers' poverty. In India, tea estate workers' wages are the lowest in the formal labour force, and many workers' living conditions are appalling (Bhowmik, 2015: 29). In Sri Lanka, poverty among tea plantation workers has been significantly higher than in other sectors (Romeshun and Fernando, 2015).

Colonial "plantation patriarchy" has justified women being relegated to the labour-intensive task of plucking and tipping tea. They are paid less while they work longer hours than their male counterparts, and are poorly represented in trade union leadership and other decision-making positions (Kurian and Jayawardena, 2017). Men tend to dominate work in the tea factory, involved in the processing and manufacturing of tea. Men generally supervise female workers, and are also employed as security persons, drivers, pruners, or sprayers (Lalitha et al., 2013: 22-23; Sharma, 2016: 119, 123).

Intersecting with these gender features, their ethnic background, caste, and poverty has distinguished the migrant labour brought in by colonial planters from local populations. Two centuries later, their descendants - so-called hill-country Tamils in Sri Lanka, as well as Adivasi ${ }^{6}$ and Nepali tea plantation workers in India - are still often perceived as "migrants." Over 90\% of workers on Tamil Nadu tea estates are from the scheduled castes (Labour Bureau, 2009: 19). Their social isolation corroborates and widens class differences in the estate and continues to guarantee a captive labour force at low wages (Makita, 2012: 89).

It took nearly a century for unionism to emerge on the plantations of India and Sri Lanka. While tea workers in India were not allowed to organise under British colonial rule, with Independence, plantation workers became increasingly unionised (Sen, 2015: 538). In 1951, they gained additional rights through the Plantation Labour Act (PLA). The PLA guarantees plantation workers' social welfare, insisting that owners provide workers with housing, health care, food rations, and schooling for their children (Besky, 2008: 2). Yet, especially in tea plantations of Assam and West Bengal, the implementation of the PLA has been poor, with casualisation of work and poor housing conditions as the most pressing results (Bhowmik, 2011: 242243; Borah, 2014: 83). Unions on Sri Lankan plantations started emerging in the 1930s, with the right of workers to form unions formally accepted through the Seven Point Agreement in 1940 Jayawardena and Kurian, 2015: 177).

Nowadays, in both India and Sri Lanka, the level of plantation workers' unionisation is high. According to the Indian Labour Bureau (2009: 38), 100\% of the plantation workforce in Assam and Kerala are unionised, followed by $70 \%$ of workers in Tamil Nadu. Most trade unions are affiliated to political parties. In Assam, tea garden labourers have almost exclusively been represented by the Assam Cha Mazdoor Sangha (ACMS), which is affiliated to the Congress party. It has been argued that this "union monopoly" effectively denies the tea workers in Assam freedom of association (Gothoskar et al., 2010: 10).

\footnotetext{
6 "Adivasi" refers to the original inhabitants of a given place. It is a term commonly used to refer to different tribal groups in India. They belong to the most marginalised segments of the Indian population.
} 
While recent estimates of unionisation in Sri Lanka's estate sector are hard to come by, Samarasinghe (1993: 336) states that, in the 1990s, nearly $85 \%$ of tea workers were members of the Ceylon Workers Congress (CWC), which is also a powerful political party at the national level. In recent years, the CWC's earlier predominance has given way to a greater spectrum of unions, supported by other political parties. Yet, while workers acknowledge that trade unions in the Sri Lankan plantation industry represent the workers to the management, there is also heavy criticism of the self-serving nature of the unions and their leaders, as well as of the lack of true representation (Gunetilleke et al., 2008: 37, 50-51).

Although women tea plantation workers are paying members and participate in strikes and other forms of industrial action, they are rarely represented in the trade union leadership. A key reason for this invisibility is the fact that, besides their longer working hours compared to males, women are expected to take on work in the household and for care, leading to their greater time poverty (Jayawardena and Kurian, 2015: 303-304). Moreover, women workers view trade unions as "[...] a political and male domain and do not want to get involved in its activities" (Borah, 2014: 79). As a result of this lack of a collective voice, concerns of special importance to women have historically received a low priority on trade union agendas (Samarasinghe, 1993: 336).

These industrial relations shape tea plantation workers' wages. In Sri Lanka and the Indian state of Assam, plantation workers' wages are determined through collective bargaining. In Sri Lanka, the operational collective bargaining agreement (CBA) within the plantation sector was signed in October 2016, one and a half year after the previous agreement lapsed. The trade unions asked for the daily labour wage to be increased to $\operatorname{LKR}^{7} 1,000$ from the rate of LKR 620 that had prevailed since 2013. The government and employers agreed on a daily rate of LKR 730, pegged to higher daily yields. This result led to further protests by workers on several plantations in October 2016.

In Assam, plantation workers' daily wages are determined through collective bargaining between the sectoral employers' association and the ACMS (Sharma, 2016: 119). In contrast to South Indian states, the wages of tea plantation workers in Assam contain an in-kind portion in the form of subsidised food rations alongside a cash wage, representing about 30\% of the cash wage (Bhowmik, 2005: 4104; Gothoskar, 2013: 39). The wage agreement signed on February 2015 stipulated a daily base wage of INR 126 for 2016 (ACMS, 2015), a level that Bhowmik (2015: 29) does not even consider a subsistence wage for workers in informal employment.

In South Indian tea plantations, the state has a stronger role in wage determination. In Tamil Nadu, the minimum wage is set by minimum wage fixation committees (Glocal Research/ICN, 2016: 14). The present daily rate for tea workers in Tamil Nadu is INR 241.31. In Kerala, by contrast, the wage is decided on the basis of tripartite negotiations and the same is declared as minimum wage. In 2016, the daily wage there was INR 310.04 (Das, 2017).

\footnotetext{
${ }^{7}$ During the time of the field research, 1 euro equalled LKR 152.08 and INR 71.22.
} 
In fact, most tea workers' wages are a mix of time- and piece-rated payments. The daily base wage requires workers to harvest a stipulated minimum quota. The base wage is combined with a piece-rated incentive, which encourages tea pluckers to harvest leaves above the fixed target (Sharma, 2016: 121; Samarasinghe, 1993: 332). During peak harvesting seasons, this system allows pluckers to increase their daily earnings substantially, depending on the extra kilogrammes of leaves plucked.

\section{Fairtrade's Labour Rights Commitments as Conventions}

\subsection{Fairtrade's Labour Rights Priorities as Compromises}

The extension of Fairtrade certification to large estates in South Asia was motivated both by a concern for tea plantation workers' low wages and disempowerment, but also by the fact that crops were not produced in sufficient quantities by small producers to satisfy demand (Raynolds, 2017: 5, 9). This compromise is reflected in Fairtrade's labour rights priorities.

Fairtrade's commitments to a living wage and workers' collective rights foreground the compatibility of workers' right to a secure livelihood with companies' productivity. Fairtrade's Strategy simultaneously underlines the benefits of a living wage for workers' poverty alleviation and for companies' higher productivity and lower costs (Fairtrade International, 2012: 3). It goes further than this framing of a living wage as a win-win for workers and employers by emphasising the need for sustainable businesses as a necessary condition for the payment of living wages (Fairtrade International, 2012: 3).

Fairtrade frames its second key labour rights commitment in synergistic terms too. Company-level social dialogue between workers" organisations and management following the model of "mature systems of industrial relations" is assumed to counter the management's influence in the estate (Raynolds, 2014: 508). In this model, frequent dialogue between workers and employers covers "not just workers' wages and work conditions but also [...] production, productivity problems and solutions, etc." (Fairtrade International, 2012: 2). Fairtrade foresees a coordinating role for itself, involving trade unions, labour ministry representatives, and other partners in social dialogue (Fairtrade International, 2012).

The role of trade unions in the Fairtrade system has been contested. There has been disagreement regarding the way in which workers should be organised in large enterprises, with banana unions and their allies being most vocal in demanding the recognition of unions as plantation workers' foremost representatives (Raynolds, 2017: 1482). In contrast to the 2012 strategy, however, which uses the broader term worker organisation throughout, the formulation of Fairtrade's Standard represents a compromise: it requires workers organising into democratic associations, but these could be workers' organisations or unions (Raynolds, 2017: 1478). 


\subsection{Conceptualising Fairtrade Standards as Conventions}

Convention theory investigates the role and negotiation of competing sets of norms, or conventions, in the coordination of transactions. Conventions are "both guides for action and collective systems to legitimise those actions that can be submitted to testing and discussion, leading to compromises and possibly defeat" (Ponte, 2016: 13). A convention perspective therefore helps to shed light on the conflicting evaluations of Fairtrade's labour programme.

Convention theory commonly distinguishes norms governing the domestic, civic, market, and industry realms associated with specific modes of evaluation. ${ }^{8}$ Tradition and personal care are common principles of "domestic" conventions. They are evaluated based on reputation. While Fairtrade's effort to challenge the historically exploitative character of international trade through the establishment of trust between producers and consumers has been understood as being governed by domestic norms (Raynolds, 2002: 409-410), their emphasis on the positioning in chains of personal dependence weakly equips them to act from a distance (Boltanski and Thévenot, 2006: 164). "Civic" conventions are organised by the principle of solidarity and assessed on the basis of their benefit to society. Given this role of collective benefit, adequate representation of the group is crucial for the evaluation of civic conventions (Ponte, 2016: 14). Raynolds (2017: 1486) understands the Strategy's living wage requirement and pro-active support for worker organisation as a reassertion of Fairtrade's founding civic norms. Competition, by contrast, is a shared principle of "market" conventions. They are judged by price (Boltanski and Thévenot, 2006: 196). These principles, too, are relevant for the governance of Fairtrade, especially since certified products have entered conventional supermarkets' shelves. Finally, evaluated through their productivity, "industrial" conventions share the principle of efficiency (Boltanski and Thévenot, 2006: 204). The translation of Fairtrade civic principles into standardised certification procedures to enable upscaling is an example thereof.

The civic conventions so central to Fairtrade's approach can have diverse underpinnings. Drawing on Dolan (2008), Riisgaard (2015: 125-127) highlights that Fairtrade's certification Standard is characterised by a liberal understanding of civic norms. Rooted in the European Enlightenment ideal of the autonomous subject, the standards identify individuals rather than groupings such as trade unions as rights holders. Examples for liberal rights incorporated in the Fairtrade Standard relate, for instance, to individual workers' entitlement to adequate wages, occupational safety, and health leaves, as well as social security. Solidaristic provisions, by contrast, refer to the guarantee of the rights of worker organisation, e.g. to freedom of association and collective bargaining (Riisgaard, 2015: 127). Cheyns and Riisgaard (2014: 418) emphasise

\footnotetext{
${ }^{8}$ Similar to Riisgaard (2015), we focus on domestic, civic, industrial, and market conventions, as they have been used most fruitfully to understand the justification and workings of Fairtrade certification. Conventions governing the realm of inspiration have not been used in this context, probably because of their focus on the particular that eludes measure. Conventions related to fame are relevant given the role of reputation for Fairtrade. Yet, public opinion relying on visibility and identification is mainly important in Fairtrade's relation to consumers rather than to workers, which is the focus of this article.
} 
that the dominant liberal understanding of civic conventions poorly equips Fairtrade for tackling social and economic inequality.

Different authors have pointed out that the Fairtrade certification of plantations builds on a compromise between civic and industrial standards. Given its combined attention to impacts on labour and productivity, Raynolds (2014: 508) interprets the model of industrial relations described in Fairtrade's strategy as a compromise between civic and industrial conventions. While there may also be tension between the civic emphasis on rights and central industrial criteria, such as productivity increases, the shared emphasis on stability and predictability as prerequisites in both the industrial and civic world makes these conventions a good match (Riisgaard, 2015: 125). This relates to human resource management as one of the contemporary discourses that embodies this compromise. Here, "[...] ideal forms of work organization are seen as stabilizing improvements in productivity through promoting the solidarity of the work" (Gibbon and Riisgaard, 2014: 101-102). Besides, prioritising workers' secure livelihoods alongside producer companies' sustainable business, Fairtrade's strategic commitment to a living wage too reflects a compromise of industrial and civic conventions.

Civic conventions are less easily reconciled with domestic and market norms. The freedom from personal dependencies emphasised in a liberal understanding of civic norms contrasts with domestic conventions' orientation towards personal relations (Gibbon and Riisgaard, 2014: 102). It is interesting to read Fairtrade's intervention in the clientelist relations prevalent in South Asian plantation hierarchies that Makita (2012) foregrounds from this perspective. The lack of stability and predictability in the market world, by contrast, make a compromise between civic and market conventions difficult to match (Riisgaard and Gibbon, 2014: 265).

Compromises between different conventions do not emerge in an evolutionary fashion. Whereas a lack of explicit discussion of power has been critiqued in convention theory (Riisgaard and Gibbon, 2014: 262), different authors have underlined that political struggles linking workers as key industrial actors with rights as a central concern of the civic domain are required for this compromise to happen (Raynolds, 2017: 1476; Riisgaard, 2015: 124-125).

\section{Methodology 9}

For the analysis in this article, we use empirical data generated during a mixed methods study of Fairtrade's labour programme in Indian and Sri Lankan tea plantations. The study was commissioned by Fairtrade International. This association was a double-edged sword: while facilitating access to workers through management's mediation, the research team was often perceived as auditors, despite the repeated assertion

\footnotetext{
${ }^{9}$ This section draws on Siegmann et al. (forthcoming).
} 
of our independence from Fairtrade International. Both on the part of management and workers, this might have led to more emphasis on the positive effects of certification.

Through stratified random sampling, we selected three certified estates for Sri Lanka, South India, and Assam each. When the certification of one of the selected estates in Assam was withdrawn in 2016, the number of certified estates in Northeast India dropped to two. We paired each selected certified plantation with a non-certified estate in the same region. The media attention to poor working conditions in tea estates (e.g. BBC, 2015) and management's concerns about the time necessary to conduct the research made access to estates difficult and led to a lower number of non-certified estates as a result (Table 1).

Table 1: Summary Participating Estates

\begin{tabular}{|l|l|l|l|}
\hline & South India & Northeast India & Sri Lanka \\
\hline Certified estates & 3 & 2 & 3 \\
\hline Non-certified estates & 2 & 1 & 1 \\
\hline
\end{tabular}

During the period from July to September 2016, we generated data through qualitative interviews and a worker survey. More specifically, we conducted gender-segmented focus group discussions (FGDs) with workers, complemented by semi-structured key informant interviews with representatives of workers' organisations, management, and the FPC, among others. The data summarised in graphs in Section 4 are based on the primary data generated.

Simple random sampling was used to select workers for participation both in the survey and FGDs. We assumed that this procedure would produce the most robust results in terms of the statistical representativeness of the survey, and would reduce the possibility of management interference in the selection of FGD participants.

The analysis presented in Section 4 prioritises workers' perspectives. Its qualitative part is based on transcripts of interview recordings and field notes. They were coded and annotated with the support of software for qualitative data analysis. The qualitative analysis focused on aspects of the interviews that were labelled with a group of codes related to "wage" and "role of unions." Its results were compared, contrasted, and complemented with descriptive analyses of related survey data. Unless mentioned otherwise, all tables and figures provided in this article are based on the data generated through the 2016 fieldwork.

Ethical principles that informed our research include informed consent, confidentiality, and the principle of minimising possible harm to research participants. Confidentiality involved the anonymisation of all information that would otherwise enable the identification of individual participants, participating organisations, or research locations. For the analytical section that follows, this implies that little contextual information is provided in order to protect research participants' identities. 


\section{Low Wages, High Unionisation - The Relevance of Fairtrade's Labour Rights}

\section{Priorities in South Asian Tea Estates}

This section investigates the relevance of Fairtrade's labour rights priorities in South Asian tea plantations. It presents the key findings of our study regarding the guarantee of living wages, as well as support to worker organisation, and discusses them from the perspective of convention theory.

\subsection{A Living Wage for Tea Plantation Workers?}

Fairtrade's strategic commitment to a living wage is in line with South Asian tea plantation workers' priorities. Asked about what they consider key labour rights, a wage adequate to guarantee a decent standard of living features among survey participants' top priorities.

However, workers' lived experience does not match this priority. Rather, the reported daily wages in both certified and non-certified estates are in accordance with industry-wide minimum wage stipulations (Fig. 1). This corresponds to earlier studies on Fairtrade certification in India ${ }^{10}$ which find only minor if any differences in workers' wages between certified and non-certified estates (e.g. Lalitha et al., 2013; Moore, 2010).

Figure 1: Daily Wages by Certification and State (Modes, EUR)

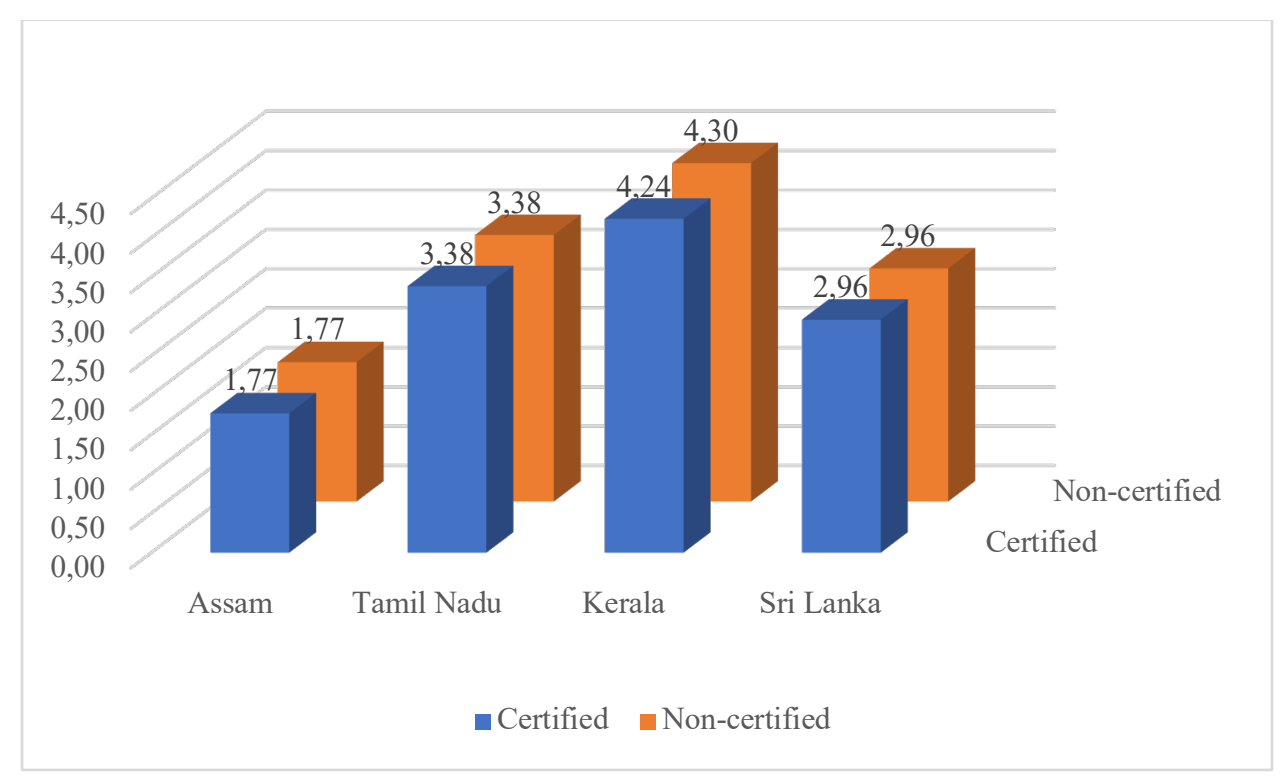

Even when the provision of in-kind wage components for Assamese tea workers is factored in, the difference in daily wages between Assamese and South Indian estates remains glaring. In absolute terms,

${ }^{10}$ We are not aware of similar studies on Sri Lanka. 
Sri Lankan wages are lower than those on South Indian plantations. Given the higher living costs in Sri Lanka, they seem meagre even relative to Assamese tea workers' earnings.

Sri Lankan tea plantation workers' income poverty is reflected in the wide gap between their earnings and expenses (Fig. 2). Sri Lankan tea pluckers ${ }^{11}$ identify a shortfall of $55 \%$ between their households' monthly estate-related wage earnings and expenditures, compared to 29\% among South Indian pluckers.

Figure 2: Tea Plucker Households' Monthly Wage Income from Estate and Expenditures by Country (EUR)

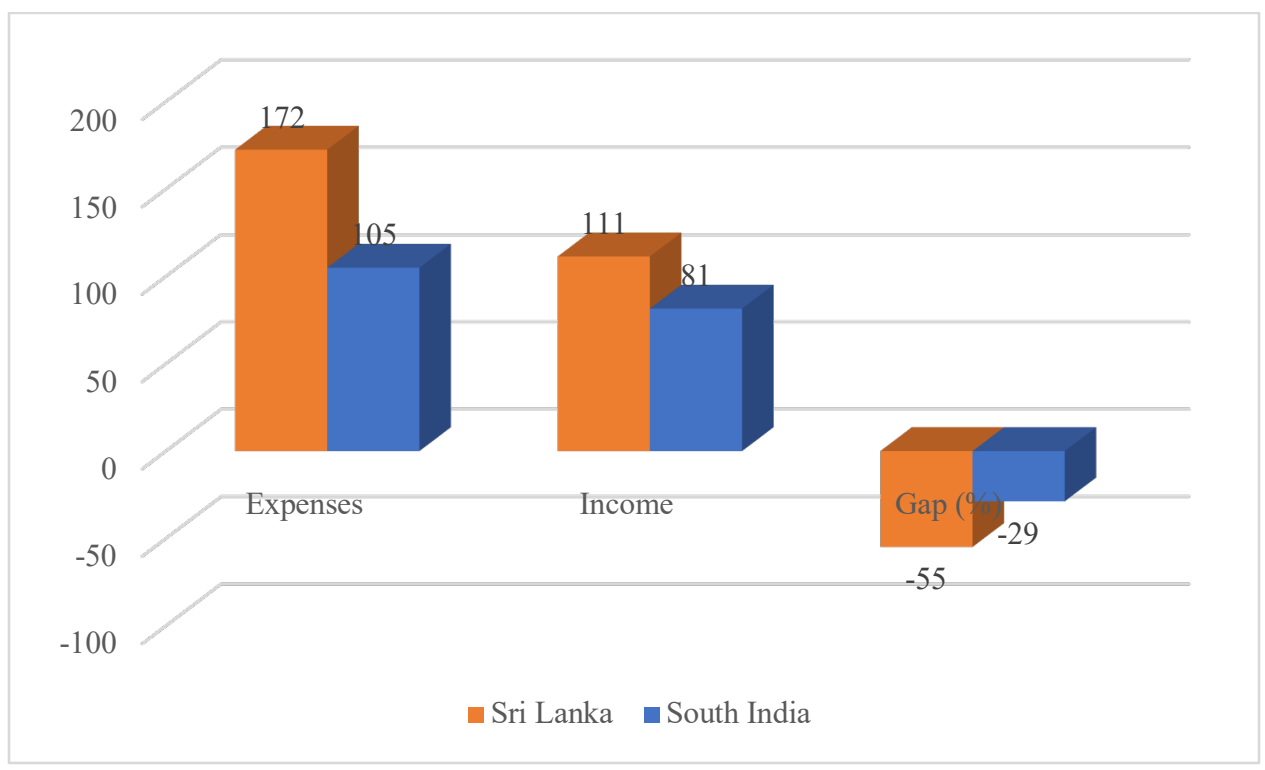

Note: For Assam, monthly expenditures could not be calculated because of missing data.

Qualitative interviews mirror this gap between workers' income and expenditures. Workers across regions and certification statuses express difficulties to make ends meet. Female pluckers in a certified estate in South India point out that their low wage forces them to make hard choices between food purchases and their children's education: "P.: When our wage was increased, the price of food increased twice as much. S.: [...] If we want to give an education to our children, we have no way to meet our food expenses."

Workers stress that significant wage increases are required to meet the level of a living wage. A South Indian tea factory worker who earns a daily wage of INR 241 specifies: "A minimum wage of 350 rupees per day should be given. Only then we can meet our expenses." Workers in Sri Lanka and Assam go further than this and demand at least to double their current wages to make ends meet.

Reflecting the identical wage levels in certified and non-certified tea estates presented in Figure 1, workers do not see a connection between Fairtrade certification and wage levels. This is exemplified by a group of

${ }^{11}$ Figure 2 focuses on tea pluckers as the largest occupational group among survey participants, resulting in more robust averages. 
male workers in a South Indian tea plantation. Asked about the relation between the estate's certification and their wages, they respond in chorus: "There is no connection." Across regions, the related wage negotiations are seen as the trade unions' responsibility. "Only the trade union can speak about the wage!" is the firm assertion of a male FGD participant in a Sri Lankan estate. This means that Fairtrade does not influence the key arena where wages are negotiated and where the organisation's commitment to civic norms of resource redistribution is put to the test.

If a connection is established, it does not relate to Fairtrade's support for a living wage. For instance, in a discussion among male workers in another certified estate in Sri Lanka about the (in)adequacy of wages to cover daily expenses, one worker demanded: "We have to talk about Fairtrade at this point. They have provided a lot of help in times like this." The "help" he invokes here is consumption smoothing through FPC-provided loans, rather than a direct contribution to the guarantee of a wage enabling a decent standard of living. His statement locates the premium in the realm of charity rather than as support for the entitlement to a living wage. This suggests an evaluation based on relations of personal dependence or domestic conventions rather than civic norms that justify the redistribution of resources and challenge class-based hierarchies.

The compliance with minimum wage levels masks increasing work pressure resulting from rising targets for the tea leaf harvest, among others. Paradoxically, Fairtrade certification even contributes to such wage erosion. A male fieldworker in an organically certified estate in Assam reports:
As the estate became organic, the work load has increased. As per the current work arrangements, we have to work for two to three days to complete a task to get a day's wage. For instance, when we undertake weeding or spraying, such operations are task-based and it takes two to three days to complete one full task to get the full wage of 126 rupees stipulated for a day.

His statement implies that the costs of additional labour required for organic cultivation are passed on to the workers. Linking a time-rated daily wage to workers' productivity perverts the notion of a base wage. This implementation of Fairtrade certification in a way that increases labour productivity at the expense of workers' earnings is driven by management's concern for productivity rather than by workers' entitlement to adequate wages.

This example reflects a situation in which plantation companies' interest in productivity reigns. It contrasts with the win-win scenario for workers and companies formulated in the Fairtrade strategy that marries concern for both civic and industrial norms. This outcome is similar to Makita's (2012: 105-6) findings. Her case study of a certified plantation in Darjeeling leads her to expect plantation management's interests to prevail in the negotiation between civic and industrial norms. Fairtrade's commitment to civic conventions aiming at greater equality - tamed anyway through the emphasis on win-win situations for both workers and management - seems irrelevant in the practice of wage payments. 


\subsection{Partnering with Workers' Organisations?}

Contrasting with their low wages, South Asian tea plantation workers' unionisation is high. With the exception of only a handful of workers - all employed in certified estates - survey respondents unanimously state that they are union members. Does this high degree of collective organisation empower plantation workers, putting to the test Fairtrade's commitment to the civic norm of a more level playing field between labour and capital? While workers describe plantation unions as crucial actors to negotiate higher wages, our results do not suggest a clear-cut positive answer.

Many workers perceive their unions as ineffective. Against the backdrop of dilapidated housing conditions as well as the ACMS's regional union monopoly, a factory worker on a certified estate in Assam sketches a lack of attention to workers' grievances on the part of unions:

\footnotetext{
Many times, our complaints do not get adequate attention from the workers' union or the management and hence, many requests, such as improvement of the [worker housing], etc. remain unattended.
}

Women workers highlight stark gender inequality in trade union representation. Even a female union representative in a certified estate in South India admits that, usually, only men attend trade union meetings. A co-plucker adds: "Even if we tell [the union about our problems], nothing will happen." This effective exclusion of women from trade union meetings mirrors the findings of earlier studies. It contrasts with the ambition of Fairtrade's Gender Strategy to support "gender equality and women's empowerment at the producer organization level" (Fairtrade International, 2016: 2). These recently formalised civic norms that challenge the "plantation patriarchy" have little relevance in the practice of certification. Sen (2009: 106) therefore concludes that by assuming that the presence of trade unions serves as a vehicle for women's empowerment, Fairtrade certification turns a blind eye to patriarchal structures that silence female workers' voices in male-dominated union politics.

Women's marginal role in trade unions alongside their time poverty constrains women workers' collective agency more than that of their male colleagues. This is reflected in the fact that - beyond wide regional differences - overall, women are less confident that they can take collective initiatives to improve their working conditions (Fig. 3). No systematic role of Fairtrade certification comes to the fore here. Similar experiences of trade unions as gendered spaces triggered the 2015 mobilisation of women workers in a Keralite tea estate during which female workers refused representation by male-dominated trade unions and successfully demanded a wage hike (Kamath and Ramanathan, 2017). It may explain South Indian women workers' comparatively higher confidence in their ability to collectively improve working conditions in their estates.

\section{Figure 3: Workers' Confidence in Collective Agency by Region, Certification, and Gender}




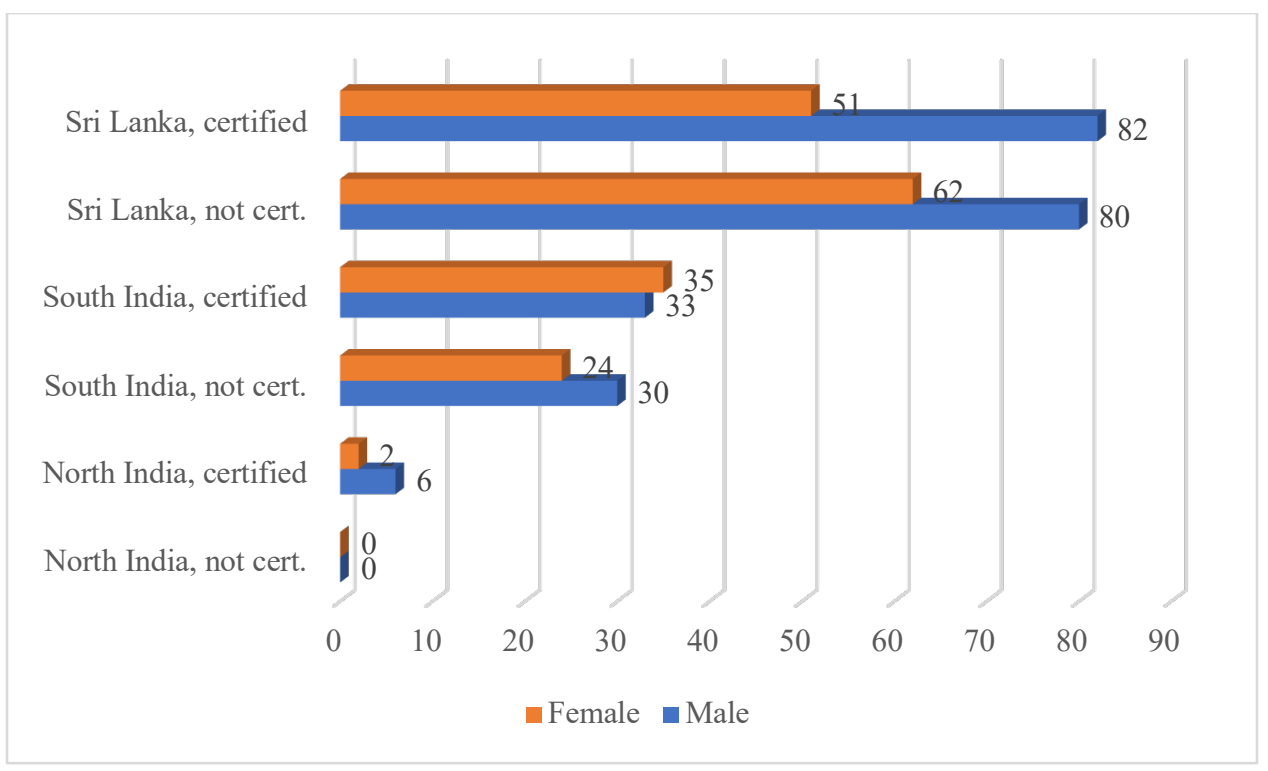

The widespread lack of trade unions' credibility explains efforts to keep unions out of workers' affairs. In this context, union involvement is often referred to synonymously with "politics" as most unions are linked with political parties. A male FPC member in a Sri Lankan estate delineates the boundaries between FPC's and trade unions' mandates in the following way:

Fairtrade has told us we cannot do anything related to politics or support for individual needs. If politicians [trade union leaders] are doing something, we won't get involved. We cannot make a road because it's related to politics. We cannot spend money for that. We can do only common activities. The union leader can't get involved in the Fairtrade committee. People who are involved in politics cannot get in.

This distinction between unions' "political" and other actors" "common" activities veils the fact that management, too, has distributive interests. Through industry associations, estate companies participate in the same "politics" of collective bargaining as plantation unions, but with structurally different interests. This begs the question of whether plantation unions' sectoral wage bargaining is excluded from Fairtrade's synergistic vision of company-level industrial relations. Raynolds (2014: 504) warns that while companybased social dialogue may promote trust, it simultaneously reinforces industrial conventions, suggesting that discussions focus on productivity alongside wages and working conditions. Thus, Fairtrade's civic vision of "mature systems of industrial relations" boils down to a productivity-enhancing industrial convention. This conclusion is in line with other authors' observations that the implementation of certification norms often fails to bring into play a plurality of conventions, but tends to favour industrial efficiency (Cheyns and Riisgaard, 2014: 414).

The separation of unions' "political" and management's "common" or neutral role is reflected in their respective influence in the FPC. Compared to management's dominance, especially in India, which was also identified in earlier studies (Makita, 2012: 98-99; Moore, 2010: 16-19; Sen, 2009: 109), survey participants consider trade unions' influence in the FPC marginal (Fig. 4). 


\section{Figure 4: Influence in the FPC by Type of Member and Region}

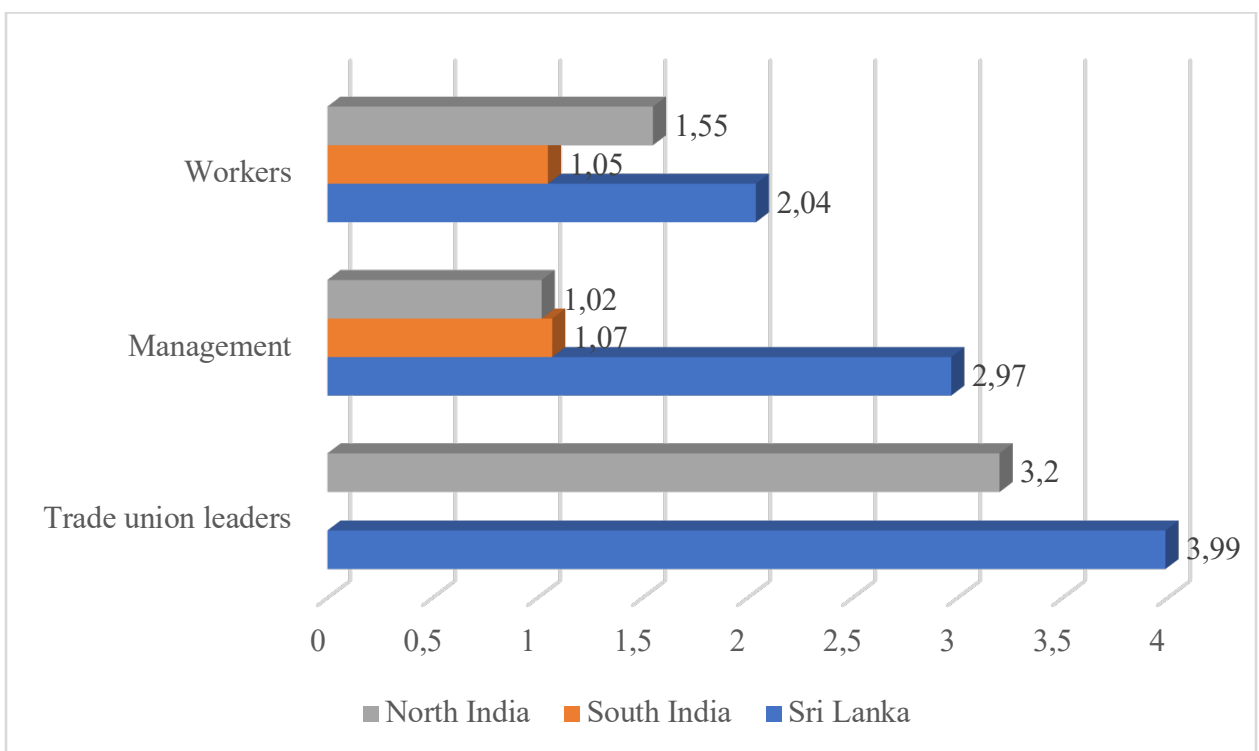

Note: Workers' perception of the respective FPC members' influence ranges from $1=$ Extremely influential to $5=$ Not at all influential. Data for trade union leaders are missing for South India as respondents were not aware of leaders' representation in the FPC.

In a few certified estates, however, trade unions do have a role in FPC governance. Some union representatives are FPC members. In one South Indian tea estate, unions' role even includes the appointment of FPC members. A female FPC member in this estate points out, however, that this does not imply collaboration between the two bodies: "There is no relation between the union and the Fairtrade committee." According to her, this separation of roles prevents a concentration of knowledge, and probably power, in the hands of a few workers. Is this related to her exclusion from male-dominated union spaces? Implicitly, she also suggests that the FPC is more representative than the unions when she explains: "Fairtrade money is mainly earned by workers, right? Hence, workers have been appointed to take care of it." This suggestion may be rooted in the fact that, in contrast to trade unions, most FPCs have a balanced representation of female and male workers.

Other than foreseen in its Strategy and Standard, Fairtrade does not support unions' negotiations of moves towards a living wage. The distinction between "common activities" involving both workers and management as opposed to the realm of "politics" associated with union actors provides a useful analytical prism here. It separates Fairtrade from unions' 'political' role. 'Politics' is a layered notion in this context. Obviously, it refers to plantation unions' intimate relations with political parties both in India and Sri Lanka, reflected, for instance, in workers' synonymous use of the terms "politician" and "union leader." Implicitly, "politics" also refers to the redistributive struggles in which trade unions are engaged through collective bargaining. These, too, are framed as lying beyond Fairtrade's intervention in the tea chain. In contrast to 
a solidaristic understanding of civic conventions as aiming for greater equality, workers', trade unions', and FPC representatives' views of Fairtrade as confined to individual support through premium investments reflects a liberal understanding of certification norms.

\section{Discussion: Happy Marriage or Defeat of Fairtrade's Civic Norms?}

Our findings show that Fairtrade's commitment to key labour rights guarantees does not survive the test of certification in South Asian tea plantations. Rather than representing a happy marriage between civic and industrial norms, the latter reign in Fairtrade's practice of certification: in theory, Fairtrade's strategic commitment to a living wage reflects a compromise between industrial and civic conventions. In practice, however, the wide gulf between living wages and South Asian tea plantation workers' actual earnings suggests that certification represents a "ritual of verification" (Loconto, 2010: 200) rather than a norm shaping redistributive practices. As a result, productivity trumps poverty alleviation. Similarly, while Fairtrade's Strategy emphasises that support for worker organisation can both be a lever for workers' empowerment and contribute to more sustainable businesses, in the practice of certification, collective labour rights are separated from Fairtrade's mandate. Such positioning outside the "political" realm inhabited by trade unions implies that Fairtrade's commitment to redistributive and egalitarian norms is relinquished in the practice of certification.

The discussion in the previous section brings to the fore that the intersection of Fairtrade's labour rights commitments with social hierarchies at the level of the estate hampers their effectiveness for a living wage and workers' empowerment. To date, the colonial roots of the plantation economy imply that class relations map onto personal dependencies steeped in hierarchies of caste and ethnicity. Fairtrade's emphasis on dialogue-based trust in industrial relations does not challenge but rather reinforces these paternalistic structures, thus supporting companies' interest in productivity.

Workers' misrepresentation is another obstacle for civic norms to guide South Asian tea plantations' certification. Apparent as it is in the distrust in unions that many workers express, it is aggravated by women workers' marginalisation in trade unions and the broader "plantation patriarchy." This chasm raises pressing questions about which estate institutions effectively represent workers' interests. As Ponte (2016: 14) emphasises, the representation of collective interests is crucial for the evaluation of civic conventions. Some of our findings reflect that the FPC may provide an alternative, more gender-equal - albeit limited - space for expressing and redressing some of the workers' grievances. Given its limited mandate and the influential role of management advisors in the FPC, however, it does not offer an alternative to the trade union representation of workers' labour rights concerns.

Representative justice goes beyond industrial relations, though. As outlined above, workers' marginalisation in South Asian tea plantations has been shaped at the intersection of hierarchies of coloniality, class, ethnicity, and gender. These intersections produce the subordination of female tea pluckers in occupational hierarchies in the estate, as well as in the male-dominated trade unions described above. They go beyond 
that to include the discrimination that Adivasi workers in Indian tea gardens and Tamil labourers in Sri Lankan plantations face, for instance. While reformulations of the Standard as well as the recently formulated Fairtrade Gender Strategy take on board important criticism and represent steps in the right direction (Loconto, 2015), Fairtrade's approach does not address the injustices that emerge from workers' social and political marginalisation. Highlighting that distributive or liberal formulations of global justice risk 'crowding out' such cultural and social differences, Besky (2015: 1156) stresses that: "It is essential in postcolonial contexts to understand the multiplicity of forms of injustice before attempting to do justice."

Last but not least, the injustices experienced by South Asian tea plantation workers are a result of their marginal position in the global tea chain. In the practice of Fairtrade certification, the role of powerful actors in this chain beyond the estate is disregarded altogether. As pointed out above, the dominance of a few multinationals in the global tea value chain enables them to capture a significant proportion of value. Yet, Fairtrade's model of industrial relations emphasises the primacy of the direct employment relationship between worker and management in a supplier company. As Miller et al. (2011: 15) point out, a major criticism of such an establishment-focused approach is that it does not consider the profound restructuring of industrial relations through global value chains that creates sweatshop conditions in the first place. This represents a key obstacle for the redistribution of value towards plantation workers.

In sum, the suspension of a solidaristic content of Fairtrade's certification norms confines the scope of redistribution to the level of the plantation. Value is syphoned off and efforts for its distribution take place elsewhere in the tea value chain, while struggles for recognition are hardly featured in Fairtrade's certification approach. In the practice of certification of South Asian tea plantations, these dynamics lead to a defeat of Fairtrade's civic norms, which are overruled by industrial concerns for productivity.

\section{Outlook}

Our sobering findings echo earlier doubts as to whether working conditions in plantations can ever be fair (Besky, 2008; Jaffee, 2010). In this context, is it possible at all to identify scenarios in which Fairtrade certification does effectively contribute to guaranteeing plantation workers' labour rights? Earlier studies point to the contested nature of Fairtrade norms, opening the possibility that workers' and producers' expectations from Fairtrade can serve as a launching pad for critical counter-politics (Sen and Majumder, 2011: 31). They serve as reminders of another crucial insight of convention theory, namely that political struggles are required for compromise between different conventions to emerge.

Historically, Fairtrade's labour programme did not arrive in South Asia's tea estates as a result of workers' demands. In contrast for instance to Latin American banana unions' forceful and critical engagement with Fairtrade's ability to bring about meaningful gains for plantation workers (Raynolds, 2017: 1481), the current separation between Fairtrade and unions' mandates in India and Sri Lanka contributes to a situation in which tea plantation workers do not tend to link Fairtrade to their political struggles. 
We argue that a more worker-driven certification system has the potential to create space for a greater relevance of Fairtrade's labour rights commitments. Internally, this involves workers' firmer inclusion in the governance of the Fairtrade system, e.g. by stepping up worker representation in Fairtrade's Network of Asia and Pacific Producers (NAPP). In 2019, only one out of fifteen members of the NAPP board represents workers, while holding an office staff position herself. Workers' representation on equal footing with plantation companies and smallholder representatives would enable "critical participation," challenging the dominance of industrial conventions in certification practices (Cheyns, 2014: 441; Cheyns and Riisgaard, 2014: 415).

Externally, a more worker-driven approach to certification implies that Fairtrade should join and help forge coalitions around workers' interests. So far, Fairtrade has been a bystander in workers' struggles, such as the 2015 women workers' strike in a Keralite tea plantation. Putting Fairtrade International's commitment to collaboration with trade unions as well as to affirmative action regarding gender and caste balance into practice would be important concrete steps towards a more worker-driven Fairtrade system. These steps would have the double benefit of providing bottom-up support for the enforcement of the Fairtrade Standard's labour rights commitments and of contributing to the required union renewal on tea plantations.

The authors

Karin Astrid Siegmann

Sajitha Ananthakrishnan

Karin Fernando

K J Joseph

Romeshun Kulasabanathan

Rachel Kurian 


\section{Bibliographical References}

ACMS (Assam Chah Mazdoor Sangha), 2015, Memorandum of Settlement with Employers' Associations, Dibrugarh, ACMS, 26 February.

Besky S., 2015, “Agricultural Justice, Abnormal Justice? an Analysis of Fair Trade's Plantation Problem”, Antipode, vol. 47, n 5, p. 1141-1160. DOI: 10.1111/anti.12159

Besky S., 2008, "Can a Plantation be Fair? Paradoxes and Possibilities in Fair Trade Darjeeling Tea Certification", Anthropology of Work Review, vol. 29, n 1, p. 1-9. DOI: 10.1111/j.1548-1417.2008.00006.x

Bhowmik S. K., 2015, “Living Conditions of Tea Plantation Workers", Economic and Political Weekly, vol. 50, $n^{\circ} 46$, p. 29-32.

Bhowmik S. K., 2011, "Ethnicity and Isolation: Marginalization of Tea Plantation Workers”, Race/Ethnicity: Multidisciplinary Global Contexts, vol. 4, n ${ }^{\circ}$ 2, p. 235-253. DOI: 10.2979/racethmulglocon.4.2.235

Bhowmik S. K., 2005, “Tea Plantation Workers' Strike: Workers Lose Out on Wages”, Economic and Political Weekly, vol. 40, n³ 38, p. 4103-4105.

Boltanski L., Thévenot L., 2006, On Justification: Economies of Worth, Princeton, Princeton University Press.

Borah P., 2014, The Impact of Trade Unions on Tea Plantation Workers: A Study of Dibrugarh District of Assam, Dissertation submitted to Sikkim University for Award of the Degree of Master of Philosophy, Gangtok, Sikkim University.

BBC (British Broadcasting Corporation), 2015, "The Cost of a Cuppa”, Radio 4, 13 September, http://www.bbc.co.uk/programmes/b068xg86 (Accessed July 2019).

Cheyns E., 2014, “Making 'Minority Voices’ Heard in Transnational Roundtables: The Role of Local NGOs in Reintroducing Justice and Attachments", Agriculture and Human V alues 31(3): 439-453.

Cheyns E., Riisgaard L., 2014, "Introduction to the Symposium", Agriculture and Human V alues 31(3): 409423, http://agents.cirad.fr/index.php/Emmanuelle+CHEYNS/Publications (Accessed July 2019).

Das A., 2017, "Cash Push for Tea Wage", The Telegraph, 4 January, telegraphindia.com, https://www.telegraphindia.com/1170104/isp/business/story 128386.jsp (Accessed July 2019).

Dolan C. S., 2008, "In the Mists of Development: Fairtrade in Kenyan Tea Fields", Globalizations, vol. 5, $n^{\circ}$ 2, p. 305-318. DOI: $10.1080 / 14747730802057787$

Fairtrade International, 2018, Monitoring the Scope and Benefits of Fairtrade, Bonn, Fairtrade International.

Fairtrade International, 2016, Gender Strategy: Transforming Equal Opportunity, Access and Benefits for All, Bonn, Fairtrade International.

Fairtrade International, 2014, Fairtrade Standard for Hired Labour, Bonn, Fairtrade International.

Fairtrade International, 2012, A New Workers Rights Strategy for Fairtrade, Bonn, Fairtrade International. 
FAOSTAT (FAO Statistics Division), 2019, FAOSTAT database, http://www.fao.org/faostat/en/\#home (Accessed July 2019).

Gibbon P., Riisgaard L., 2014, “A New System of Labour Management in African Large-Scale Agriculture?", Journal of Agrarian Change, vol. 14, nº 1, p. 94-128. DOI: 10.1111/joac.12043

Glocal Research/ICN (India Committee of the Netherlands), 2016, Certified Unilever Tea - A Cup Half Empty, Utrecht, ICN.

Gothoskar S., 2013, "This Chay is Bitter: Exploitative Relations in the Tea Industry", Economic and Political Weekly, vol. 47, n $^{\circ} 50$, p. 33-40.

Gothoskar S., Sukthankar A., Goss J., 2010, In Cold Blood: Death by Poison, Death by Bullets. Human Rights Violations at the Tata/Tetley-controlled Powai Tea Estate in Assam, India, Sydney, IUF Asia \& Pacific.

Gunetilleke N., Kuruppu S., Goonasekera S., 2008, The Estate Workers' Dilemma: Tensions and Changes in the Tea and Rubber Plantations in Sri Lanka, Colombo, CEPA.

Indian Tea Association, 2019, Production - Indian Tea- Districtwise, https://www.indiatea.org/uploads/scenerio_image/1496838969.pdf (Accessed July 2019).

Jaffee D., 2010, "Fair Trade Standards, Corporate Participation, and Social Movement Responses in the United States", Journal of Business Ethics, vol. 92, n 2, p. 267-285, https://www.jstor.org/stable/27919142 (Accessed July 2019).

Jayawardena K., Kurian R., 2015, Class, Patriarchy and Ethnicity on Sri Lankan Plantations - Two Centuries of Power and Protest, New Delhi, Orient Blackswan.

Kamath R., Ramanathan S., 2017, 'Women Tea Plantation Workers' Strike in Munnar, Kerala: Lessons for Trade Unions in Contemporary India", Critical Asian Studies, vol. 49, $\mathrm{n}^{\circ} 2$, p. 244-256. DOI: $\underline{10.1080 / 14672715.2017 .1298292}$

Kurian R., 1989, State, Capital and Labour in the Plantation Industry in Sri Lanka 1934-1984, PhD thesis, Amsterdam, University of Amsterdam.

Kurian R., Jayawardena K., 2017, "Plantation Patriarchy and Structural Violence: Women Workers in Sri Lanka", in Hassankhan M. S., Roopnarine L., Mahase R. (ed.), Social and Cultural Dimensions of Indian Indentured Labour and its Diaspora: Past and Present, London, Routledge, p. 25-50.

Labour Bureau, 2009, Socio-economic Conditions of Women Workers in Plantation Industry 2008-09, Chandigarh, Labour Bureau, Ministry of Labour \& Employment.

Lalitha N., Nelson V., Martin A. et al., 2013, Assessing the Poverty Impact of Sustainability Standards: Indian Tea, London, University of Greenwich.

Loconto A., 2015, “Can Certified-Tea Value Chains Deliver Gender Equality in Tanzania?”, Feminist Economics, vol. 21, nº 3, p. 191-215. DOI: 10.1080/13545701.2014.1001765 
Loconto A., 2010, "Sustainably Performed: Reconciling Global Value Chain Governance and Performativity", Joumal of Rural Social Sciences, vol. 25, $\mathrm{n}^{\circ} 3$, p. 193-225, http://journalofruralsocialsciences.org/pages/Articles/JRSS $\% 202010 \% 2025 / 3 / J R S S \% 202010 \% 2025 \% 2$ 03\%20193-225.pdf (Accessed July 2019).

Makita R., 2012, "Fair Trade Certification: The Case of Tea Plantation Workers in India", Development Policy Review, vol. 30, n 1, p. 87-107. DOI: 10.1111/j.1467-7679.2012.00561.x

Miller D., Turner S., Grinter T., 2011, "Back to the Future? A critical reflection on Neil Kearney's mature systems of industrial relations perspective on the governance of outsourced apparel supply chains", Working Paper 2011/08, Manchester, University of Manchester.

Ministry of Plantation Industries of Sri Lanka, 2013, Statistical Information on Plantation Crops 2012, Colombo, Ministry of Plantation Industries, http://plantationindustries.gov.lk/web/images/pdf/publications/plantation_sector_statistical_pocket_b ook 2012.pdf (Accessed July 2019).

Mohan S., 2016, "Institutional Change in Value Chains: Evidence from Tea in Nepal”, World Development, vol. 78, p. 52-65. DOI: $10.1016 / j . w o r l d d e v .2015 .10 .004$

Moore L. B., 2010, "Reading Tea Leaves: The Impact of Mainstreaming Fair Trade”, LSE Working Paper Series No.10-106, London, LSE.

Ponte S., 2016, "Convention Theory in the Anglophone Agro-Food Literature: Past, Present and Future", Journal of Rural Studies, n 44, p. 12-23. DOI: 10.1016/j.jrurstud.2015.12.019

Raynolds L. T., 2017, "Fairtrade Labour Certification: The Contested Incorporation of Plantations and Workers", Third World Quarterly, vol. 38, n 7, p. 1473-1492. DOI: 10.1080/01436597.2016.1272408

Raynolds L. T., 2014, "Fairtrade, Certification, and Labor: Global and Local Tensions in Improving Conditions for Agricultural Workers", Agriculture and Human Values, vol. 31, n 3, p. 499-511. DOI: 10.1007/s10460-014-9506-6

Raynolds L. T., 2002, "Consumer/producer Links in Fair Trade Coffee Networks", Sociologia Ruralis, vol. 42, nº 4, p. 404-424. DOI: $10.1111 / 1467-9523.00224$

Reed D., 2009, "What do Corporations have to do with Fair Trade? Positive and Normative Analysis from a Value Chain Perspective", Journal of Business Ethics, vol. 86, n 1, p. 3-26. DOI: $10.1007 / \mathrm{s} 10551-008-9757-$ $\underline{5}$

Riisgaard L., 2015, "Fairtrade Certification, Conventions and Labor", in Raynolds L., Bennett E. (ed.), Handbook of Research on Fair Trade, Cheltenham, Edward Elgar Publishing, p. 120-138.

Riisgaard L., Gibbon P., 2014, "Labour Management on Contemporary K Enyan Cut Flower Farms: Foundations of an Industrial-Civic Compromise", Journal of Agrarian Change, vol. 14, nº 2, p. 260-285. DOI: 10.1111/joac.12064 
Romeshun K., Fernando P., 2015, Poverty in the Estate Sector: Has It Turned the Corner?, CEPA Blog 07 May, cepa.lk, $\quad$ http://www.cepa.lk/blog/details/poverty-in-the-estate-sector-has-it-turned-the-corner-e12dc7f68939e8b4f5c525ff40899a65.html (Accessed July 2019).

Samarasinghe V., 1993, "Puppets on a String: Women's Wage Work and Empowerment among Female Tea Plantation Workers of Sri Lanka", The Journal of Developing Areas, vol. 27, n 3, p. 329-340.

Sen R., 2015, "Tea Workers-Distressed in the Organized Industry in North Bengal”, Indian Journal of Industrial Relations, vol. 50, $\mathrm{n}^{\circ}$ 4, p. 535-550.

Sen D., 2009, From Illegal to Organic: Fair Trade-Organic Tea Production and Women's Political Futures in Darjeeling, India, PhD dissertation, New Brunswick, Rutgers University.

Sen D., Majumder S., 2011, "Fair Trade and Fair Trade Certification of Food and Agricultural Commodities: Promises, Pitfalls, and Possibilities", Environment and Society: Advances in Research, vol. 2, $\mathrm{n}^{\circ} 1$, p. 29-47. DOI: $10.3167 /$ ares.2011.020103

Sharma A., 2016, "Female Labour in Tea Plantations: Labour Process and Labour Control", in Fernandez B., Gopal M., Ruthven O. (ed.) Land, Labour and Livelihoods, Cham, Palgrave Macmillan, p. 111131.

Siegmann K. A., Ananthakrishnan S., Fernando K., et al. (forthcoming), Fairtrade-certified Tea in the Hired Labour Sector in India and Sri Lanka: Impact Study and Baseline Data Collection, The Hague, ISS.

Staricco J. I., 2019, "Class Dynamics and Ideological Construction in the Struggle Over Fairness: A NeoGramscian Examination of the Fairtrade Initiative", The Journal of Peasant Studies, vol. 46, n 1, p. 96-114. DOI: $\underline{10.1080 / 03066150.2017 .1337003}$

Tea Board of India, 2016, 62st Annual Report 2015-16, Kolkata, Tea Board of India, http://www.teaboard.gov.in/TEABOARDPAGE/ODA= (Accessed July 2019). 